\title{
The population structure of the lichen Lobaria pulmonaria in the middle boreal forests depends on the time-since-disturbance
}

\author{
Roman V. Ignatenko \& Viktoria N. Tarasova \\ Department of Botany and Plant Physiology, Petrozavodsk State University, 33 Lenin St., 185910 Petrozavodsk, Russia. \\ E-mails: ocean-9@mail.ru, tarasova1873@gmail.com
}

\begin{abstract}
The population structure of the lichen Lobaria pulmonaria (L.) Hoffm. was analyzed in the Vodlozersky National Park (Karelia, Russia), for middle boreal forest stands having a time-since-disturbance spanning 80 to 450 years. To estimate the age of the last disturbance, a method of evaluation for the tree population structure was applied. The forest stand communities belonged to a successional series: middle-aged aspen - mixed aspen-spruce - pre-climax spruce - climax (old-growth) spruce forest. All thalli (1055) of $L$. pulmonaria from all substrate units (165, separately standing or lying trees and shrubs) were described within 7 sample plots of 1 ha. For each thallus, the area $\left(\mathrm{cm}^{2}\right)$ and the functional-age group were determined. The number of Lobaria thalli per ha, number of substrate units, number of substrate types (living, standing dead and lying dead trees of different species) colonized by L. pulmonaria, as well as number of substrate types on which the lichen had completed its life cycle increased with time-since-disturbance.
\end{abstract}

Keywords: Lobaria pulmonaria; middle boreal forest; succession; population ecology

\section{INTRODUCTION}

Lobaria pulmonaria (L.) Hoffm is a large epiphytic cyanolichen that is widely distributed within and beyond the Holarctic region (Yoshimura, 1971), and which inhabits old-growth forests in the boreal region. The species is considered extremely sensitive to anthropogenic impact and is used as an indicator of ecological continuity of habitats (Rose, 1992). Over the past 60 years, the world population of L. pulmonaria has declined considerably and at present time it is endangered in many countries of Western Europe (Gauslaa, 1995; Zoller et al., 1999; Gu et al., 2001; Jüriado \& Liira, 2009; Mikryukov et al., 2010; Scheidegger et al., 2012). In Russia this lichen is listed in the Red Data Book of the Russian Federation (2008) as well as in many regional Red Data Books, including the Republic of Karelia (2007).

However, it has been suggested that in the forests of the north European Russia there is no threat to Lobaria pulmonaria now or in the immediate future, even at the current rate of forest management activity (Kravchenko \& Fadeeva, 2008; Pystina \& Semenova, 2009). This assumption is significant when considering the catastrophic reduction of $L$. pulmonaria populations in the other countries of northern Europe (Walser et al., 2001; Jüriado, Liira, 2010), as well as to the southern portion of north European Russia, for example, in the Leningrad region (Istomina, 1996) and the Novgorod region (Katenina, 1999). Such favorable conclusions are often based on the analysis of the species occurrence ("presence-absence") or the number and size of thalli in different forest types, without evaluating the population structure and the potential capacity for recovery of the species in successional forest communities.

There is still insufficient data on change in the quantitative and qualitative condition of Lobaria pulmonaria in forest communities at different successional stages. Previous studies examining the effect of time since last disturbance on L. pulmonaria, often reported the species status within two categories-disturbed (managed) forests and old-growth forests, without a clear continuum applicable to forest loss and the initial conditions of forest regeneration $(\mathrm{Gu}$ et al., 2001; Scheidegger et al., 2012). However, some researchers have dealt with the longerterm dynamics of $L$. pulmonaria populations at the level of large spatial units (landscapes) (Snäll et al., 2005). This approach is based on metapopulation theory, which is represented as a network of interrelated local populations within a landscape or region (Hanski, 1999). According to this theory, the population persistence for certain species of epiphytic lichens depends on three important factors: the conditions of the region or landscape (natural conditions, the 
history of economic development, the level of anthropogenic impact), characteristics of forest communities (the structure of the tree stand, the proportion of phorophytes in the tree stand, the time since last disturbance) and features of dispersal ability (predominant mode of reproduction and distance of diaspores dispersal) (Johansson, 2006). In the boreal forest, it has been emphasized that the frequency of catastrophic disturbances has great importance for the conservation of populations: high frequency disturbance reduces the number of individuals because of decreasing time necessary for growth and dispersal, while the frequency leads to a decreasing number in the new generation of deciduous trees and therefore suitable substrate for lichens (Snäll et al., 2005).

Lobaria pulmonaria in European Russia occurs in different types of forests, but the prevailing number of locations is reported in coniferous forest communities (Potasheva \& Kravchenko, 1995; Istomina, 1996; Kravchenko \& Fadeeva, 2008; Fadeeva \& Kravchenko, 2008; Pystina \& Semenova, 2009; Ignatenko \& Tarasova, 2015; Ivanova, 2015, and others). Within this context, L. pulmonaria colonizes the bark of different trees and moss-covered rocks. In the forest communities of European Russia the main host tree for L. pulmonaria is aspen (Istomina, 1996; Kravchenko \& Fadeeva, 2008; Ivanova, 2015, etc.).

It is known that aspen forms secondary forests after the destruction of spruce communities, and is also included in old-growth spruce forests (Volkov, 2008). Epiphytic species colonize tree trunks, which are ephemeral habitat patches, and these species must track the dynamic patch network for their long term survival at the landscape level (Snäll et al., 2005). Population dynamics of epiphytic species is thus closely related to the dynamics of phorophytes in tree stands, and therefore to the forest dynamic in general. It is known that at least 400-450 years are required for total recovery of the climax spruce forest after disturbance in the middle boreal subzone in Northwest Russia (Gromtsev, 2008).

The aim of this study was to explore the quantitative parameters of the Lobaria pulmonaria thalli (occurrence, abundance, size), as well as the functional-age condition and substrate preferences of the species, in forest communities at different succession stages in the territory of the Vodlozersky National Park.

\section{MATERIALS AND METHODS}

\section{Study area}

The research was carried out in forest communities of the Karelian part of the Vodlozersky National Park located in Northwest Russia, during 2014-2015 (Fig. 1). Vodlozersky National Park is the largest $(468,300 \mathrm{ha})$ protected area in the territory of Northwest Russia, as well as in Europe as a whole (Fig. 1). The park is located in two regions: Arkhangelsk region $(337,600 \mathrm{ha})$ and in the Republic of Karelia (130,600 ha). The Park area includes Lake Vodlozero and an extensive basin of the Ileksa River, which is the lake's main tributary (mainly in Archangelsk region).

The Park territory is located in the middle boreal subzone and characterized by variation of forests, swamps and aquatic ecosystems that reflect the natural boreal zone of north European Russia. The climate is temperate, transitioning from maritime to continental, with short, cool summers and prolonged winters. The annual average air temperature is $+3{ }^{\circ} \mathrm{C}$ and the annual average precipitation ranges from 450 to 750 $\mathrm{mm}$ (Romanov, 1961). The relief is low and flat, heavily waterlogged and only in the northern portion of the Park rises to the low-mountain ridge of Vetreny Poyas (up to $350 \mathrm{~m}$ ).

The Vodlozersky National Park includes one of the largest areas in Europe of middle taiga covered with old-growth forests (Chervjakov, 2001). In the Karelian part of the Vodlozersky National Park there is predominant spruce (Picea abies, $P$. obovata, Picea $\mathrm{x}$ fennica) occupying $58 \%$ of the territory, while pine forests account for approximately 36\%. Birch (Betula pendula, B. pubescens) and aspen (Populus tremula) forest communities, which mostly regenerate following clear cuttings, fires and windfall of forests, as well as on abandoned cultivated fields, do not exceed 5\% (Ananjev \& Raevsky, 2010).

Lichenological studies in the Park area have been carried out since 1992 and a first preliminary checklist of lichens from the Karelian portion included 152 species (Tarasova \& Stepanova, 2001). Recently 188 species were also reported from the Muroigora, which is located in the Arkhangelsk portion of the Park (Tarasova et al., 2016).

\section{Study sites and data collection}

The study was performed for 7 permanent sample plots each with an area 1 ha $(100 \times 100 \mathrm{~m})($ Fig. 


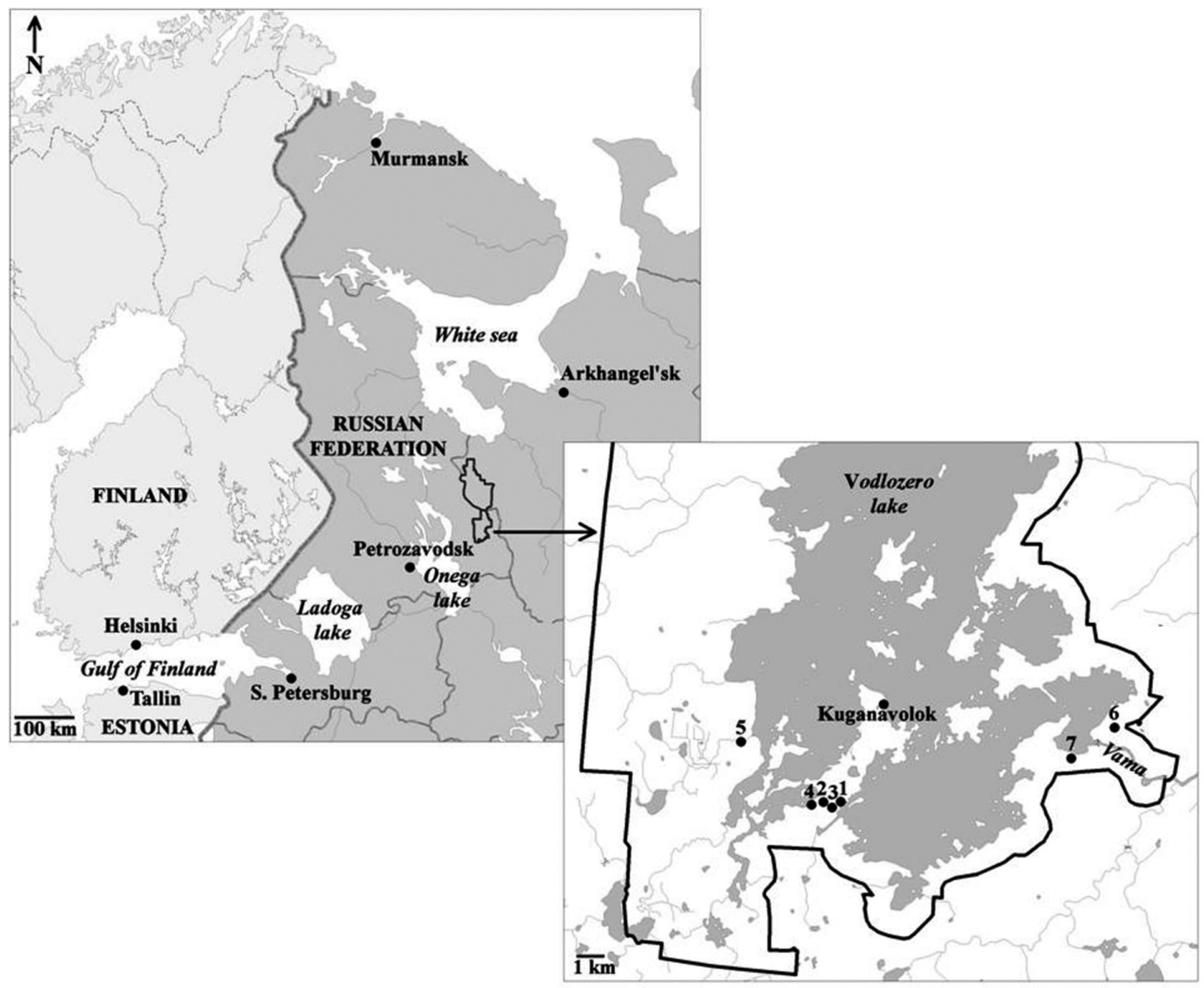

Fig. 1. The location of the study area (Republic of Karelia, NW Russia): thick line - border of Vodlozersky National Park, black circles - sample plots (additional data about sample plots see in Table 1).

1). All studied forest communities belonged to a series representing the successional pathway of recovery to climax spruce forest of the Vaccinium myrtillus - green mosses sub-type. The plots occurred on plains with a loamy moraine and without stagnant moistening. The spruce forests after fire or clear cutting mostly recover by means of a gradual change in tree species, usually transitioning through birch or aspen stands (Kazimirov, 1971; Dyrenkov, 1984). On richer soils the successional pathway includes aspen, and on poorer soils birch (Ipatov, 1960; Degteva et al., 2001).

In the current investigation, we consider the pathway of recovery for spruce forests through the aspen stage. The time-since-disturbance of the studied forest communities was established as stages of succession ranging from 80 to 450 years, with composition, structure and values for their main characteristics significantly different (Table 1). Based on established data for succession of middle boreal spruce forests (Kazimirov, 1971, Dyrenkov, 1984), the forest communities were categorized into four groups corresponding to different successional stages: 1) middle-aged aspen forest Vaccinium myrtillus - Calamagrostis arundinacea type; 2) mixed aspen-spruce forest Calamagrostis arundinacea - Vaccinium myrtillus type; 3) preclimax spruce forest Vaccinium myrtillus - green mosses type; 4) climax (old-growth) spruce forest Vaccinium myrtillus - green mosses type (Table 1). 
Table 1. The main characteristics of studied forests in Vodlozersky National Park

\begin{tabular}{|c|c|c|c|c|c|c|c|c|c|c|}
\hline \multirow[t]{2}{*}{ Type of forest } & \multirow[t]{2}{*}{$\begin{array}{l}\text { No of } \\
\text { sample } \\
\text { plot }\end{array}$} & \multirow[t]{2}{*}{$\begin{array}{l}\text { GPS } \\
\text { coordinate }\end{array}$} & \multirow{2}{*}{$\begin{array}{l}\text { Age of } \\
\text { the last } \\
\text { distur- } \\
\text { bance, } \\
\text { years }\end{array}$} & \multirow[t]{2}{*}{$\begin{array}{l}\text { Basal } \\
\text { area, } \\
\mathrm{m}^{2} \mathrm{ha}^{-1}\end{array}$} & \multirow{2}{*}{$\begin{array}{l}\text { Basal } \\
\text { area, } \\
\mathrm{m}^{2} \mathrm{ha}^{-1} \\
\text { standing } \\
\text { dead trees }\end{array}$} & \multirow{2}{*}{$\begin{array}{l}\text { Basal } \\
\text { area, } \\
\mathrm{m}^{2} \mathrm{ha}^{-1} \\
\text { fallen } \\
\text { dead trees }\end{array}$} & \multicolumn{2}{|c|}{$\begin{array}{l}\text { Proportion in } \\
\text { the tree stand, } \\
\%\end{array}$} & \multicolumn{2}{|c|}{ Age of trees, years } \\
\hline & & & & & & & Spruce & Aspen & Spruce & Aspen \\
\hline \multirow{2}{*}{$\begin{array}{l}\text { Middle-aged aspen } \\
\text { forest Vaccinium myr- } \\
\text { tillus - Calamagrostis } \\
\text { arundinacea type }\end{array}$} & 1 & $\begin{array}{l}62^{\circ} 12.001^{\prime} \mathrm{N} \\
36^{\circ} 51.114^{\prime} \mathrm{E}\end{array}$ & 80 & 29.0 & 1.0 & 2.0 & 8 & 47 & $28-48$ & $26-73$ \\
\hline & 2 & $\begin{array}{l}62^{\circ} 11.976^{\prime} \mathrm{N} \\
36^{\circ} 49.659^{\prime} \mathrm{E}\end{array}$ & 100 & 30.3 & 0.6 & 0.5 & 27 & 45 & $25-95$ & $56-103$ \\
\hline \multirow{2}{*}{$\begin{array}{l}\text { Mixed aspen-spruce } \\
\text { forest Calamagrostis } \\
\text { arundinacea -Vac- } \\
\text { cinium myrtillus type }\end{array}$} & 3 & $\begin{array}{l}62^{\circ} 11.972^{\prime} \mathrm{N} \\
36^{\circ} 51.009^{\prime} \mathrm{E}\end{array}$ & 160 & 26.5 & 3.6 & 1.5 & 53 & 22 & $28-84$ & $83-151$ \\
\hline & 4 & $\begin{array}{l}62^{\circ} 12.076^{\prime} \mathrm{N} \\
36^{\circ} 50.249^{\prime} \mathrm{E}\end{array}$ & 180 & 31.0 & 3.9 & 3.9 & 65 & 14 & $48-143$ & $67-151$ \\
\hline $\begin{array}{l}\text { Preclimax spruce forest } \\
\text { Vaccinium myrtillus - } \\
\text { green mosses type }\end{array}$ & 5 & $\begin{array}{l}62^{\circ} 13.448^{\prime} \mathrm{N} \\
36^{\circ} 45.222^{\prime} \mathrm{E}\end{array}$ & 260 & 19.3 & 2.4 & 5.8 & 64 & 2 & $46-229$ & $128-152$ \\
\hline \multirow{2}{*}{$\begin{array}{l}\text { Climax (old-growth) } \\
\text { spruce forest Vaccin- } \\
\text { ium myrtillus - green } \\
\text { mosses type }\end{array}$} & 6 & $\begin{array}{l}62^{\circ} 13.545^{\prime} \mathrm{N} \\
37^{\circ} 05.081^{\prime} \mathrm{E}\end{array}$ & 410 & 22.8 & 1.0 & 3.1 & 81 & 12 & $24-263$ & $164-198$ \\
\hline & 7 & $\begin{array}{l}62^{\circ} 13.026^{\prime} \mathrm{N} \\
37^{\circ} 03.456^{\prime} \mathrm{E}\end{array}$ & 450 & 29.3 & 0.8 & 4.8 & 89 & 9 & $31-180$ & 109-203 \\
\hline
\end{tabular}

To estimate time-since-disturbance in the studied communities, we evaluated the population structure of each tree stand (mainly spruce trees) following N. I. Stavrova et al. (2016). Thus, in the corners of sample plots we established a circular area with a radius of $2-10 \mathrm{~m}$, and measurements for all trees and seedlings (species, height, diameter of the trunk, age) were recorded. The age of 20-25 trees with different trunk diameters and heights was determined using an increment borer, and for the remaining trees using calibration curves. Based on this data, the distribution patterns for the amount and the supply of wood for spruce (Picea abies, P. obovata, Picea $\mathrm{x}$ fennica) and aspen (Populus tremula) were plotted.

The age of the last disturbance for aspen and mixed spruce-aspen communities with a threshold less than 120 years was determined as the maximum age of the oldest trees. In fact, in these communities, aspen and spruce stands are formed in one generation by trees of the same age (Kazimirov, 1971).

Considering the fact that in preclimax and old-growth spruce forests these trees of the first generation are often lost to mortality, the age of the last disturbance was estimated based on the population structure of the tree stand. For example, old-growth spruce forests with the age of the last disturbance older than 400 years are characterized by differently-aged trees (stands with a continuum of tree ages, up to a maximum age for spruce $>270$ years), with a predominance of young spruce trees (up to 90-95\%) and an equal wood supply over each age class in the stand (no more than 15\% in each class) (Kazimirov, 1971; Stavrova et al., 2016). These tree age profiles were compared to data from the literature, for which time-since-disturbance had been determined for studied communities.

All Lobaria pulmonaria thalli occurring on all types of substrates, at heights of 0-2 $\mathrm{m}$ from the ground were recorded, in 7 sample plots of 1 ha. For each thallus of $L$. pulmonaria the total area $\left(\mathrm{cm}^{2}\right)$ was estimated using a frame $(25 \times 25 \mathrm{~cm})$, as well as determining the functional-age group according to Mikhailova (2005): sterile (st) without reproductive structures; hyposorediate (s1) - with marginal soralia; mesosorediate (s2) - with abundance of marginal and single laminal soralia; hypersorediate (s3) - with marginal soralia; fertile (fert) - with apothecia; subsenile (s/sen) - with partly destroyed thallus in centre and with regenerative structures; senile (sen) - with dying lobes on which regenerative struc- 
tures arise as a result of the destruction of larger thallus. The following data for sample plots were evaluated: the total number of substrate units, the total number of standing or fallen trees and shrubs colonized by L. pulmonaria, the number of substrate types, the number of colonized tree species and their condition (living, dead standing, dead fallen). We thus defined trees of the same species in one of three possible states: living, dead or fallen tree.

The statistical processing of the results was based on a single-factor regression analysis using the linear model $y=a x+b$ (Ivanter $\&$ Korosov, 2011) in the program package of Microsoft Office Excel (2007).

\section{RESULTS}

In the spruce forests of Vodlozersky National Park, with a successional series running through the stage of an aspen tree stand, Lobaria pulmonaria occurred after 80 years from the last disturbance. In younger aspen forests (< 80 years) L. pulmonaria was not found. The earliest occurrence is for middle-aged aspen forest Vaccinium myrtillus - Calamagrostis arundinacea type with spruce seedlings. For the total area of the studied forest communities (7 ha), 1055 thalli of L. pulmonaria were recorded on 165 substrate units. The number of thalli in the different forest communities varied greatly: from 33 to 309 samples per ha. The thallus area of $L$. pulmonaria also varied significantly, from $1 \mathrm{~cm}^{2}$ to $1200 \mathrm{~cm}^{2}$.

\section{Total and average numbers of thalli}

The average number of thalli per unit of substrate and the abundance of thalli in communities (thalli/ha) was related to the time since the last forest disturbance (Fig. 2.1). With the increasing time, in the communities aged from 80 to 450 years, the number of Lobaria pulmonaria thalli increased six-fold - from 50 to 300 (Fig. 2.1). The minimum abundance of thalli per hectare $(33,87)$ was recorded in the middle-aged aspen communities. In mixed spruce-aspen forests, the abundance of thalli increased to 107, 118 thalli/ha. In preclimax and climax spruce forests the maximal abundance of thalli was recorded, and reached 139 and 262, 309 thalli per 1 ha, respectively (Table 2). Moreover, in these communities an average of 10 and 7 thalli occurred on each unique substrate unit, respectively (Table 2 ).

\section{Numbers of substrate units and substrate types}

The number of substrate units increased with increasing time since the last disturbance from $9 \mathrm{pcs} / \mathrm{ha}$ in middle-aged aspen forests to 44 pcs/ha in the climax spruce forests. The average number of substrate units was $24 \mathrm{pcs} /$ ha (Fig. 2.2).

In the studied forest communities Lobaria pulmonaria occurred on a wide range of substrates (Table 2). According to our results, 76\% of the substrate units (living, dead, fallen trees) colonized by this lichen were represented by a deciduous tree species: Populus tremula L. (59\%), Sorbus aucuparia L. (32\%), Betula sp. $(8 \%)$, Alnus incana (L.) Moench (1\%). A proportion of coniferous trees, such as Picea sp., and of Juniperus communis L., accounted for $24 \%$ of the total number of substrate units.

With the increasing time-since-disturbance, from 80 to 450 years, the number of substrates colonized by Lobaria pulmonaria increased from 5 to $8\left(R^{2}=0.67^{*}\right)$. Moreover, the substrate preferences of $L$. pulmonaria changed with the increasing time-since-disturbance. In the middle-aged aspen forests thalli usually colonized the trunks of living aspen trees with an age of $56-143$ years $(22 \%)$, as well as rowan trunks with an age of 23-92 years (36\%) (Tab. 2). In mixed aspen-spruce forests $L$. pulmonaria was often found on large aspen trees aged 67-181 years $(56 \%)$ and on standing dead aspen trees $(16 \%)$ and rowan $(24 \%)$. In preclimax spruce forest, $63 \%$ of thalli were recorded on standing dead of aspen, and $22 \%$ on old aspen trees aged 128-152 years. In the climax (old-growth) spruce forests thalli of $L$. pulmonaria had begun to actively colonize the branches of young spruce trees aged 13-67 years (Fig. 3).

The number of thalli on spruce trees increased during forest succession, and maximum values were observed in old-growth spruce forests with an age of 410-450 since their last disturbance, in which case the proportion of lichen thalli found on spruce was $45-51 \%$ of the total thalli number (Fig. 2.3, Table 2).

\section{Area of thalli}

The average area of the thalli of Lobaria pulmonaria decreased with increasing age since the last disturbance. The average area of the thalli during the period $80-450$ years since distur- 

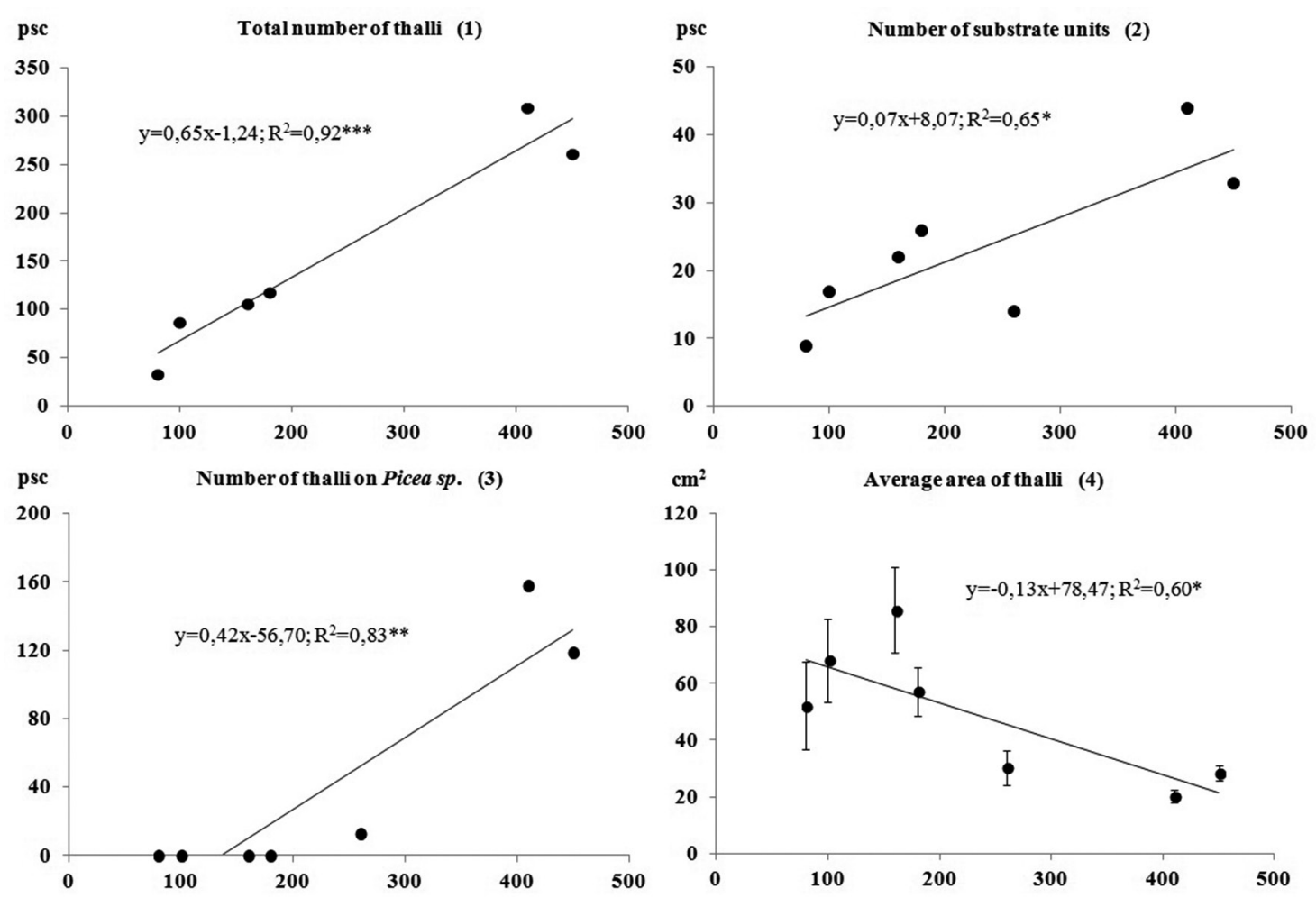

Age after the last disturbance, years

Fig. 2. Quantitative parameters for Lobaria pulmonaria in forest communities with different time periods since the last disturbance. P-value of regression coefficient $\left(R^{2}\right)$ is less than the significance level, such as $\left.0.001\left(^{(* *}\right), 0.011^{* *}\right)$ or $\left.0.05{ }^{*}\right)$.

bance decreased by a factor of 2.5 , from 60.1 $\pm 15.1 \mathrm{~cm}^{2}$ to $24.3 \pm 2.5 \mathrm{~cm}^{2}$ (Fig. 2.4). This is related to a change in the proportion of young, medium-sized individuals of L. pulmonaria contributing to the total number of thalli. Thus, in middle-aged aspen communities, the proportion of thalli with area less than $51 \mathrm{~cm}^{2}$ was $78 \%$ of the total number of thalli, while in old growth spruce forests it was $90 \%$. In middle-aged aspen forest communities the proportion of L. pulmonaria thalli with an area more than $358 \mathrm{~cm}^{2}$ was $5 \%$, and in spruce-aspen communities $9 \%$, while in climax spruce forests $0.4 \%$ (Fig. 4).

\section{Functional age-related groups of thalli}

All functional-age groups were represented within Lobaria pulmonaria populations in the study area. However, in the middle-aged aspen forests, L. pulmonaria did not form the full functional-age spectra on its main host tree,
Populus tremula (Table 3). In these communities the thalli of $L$. pulmonaria had a complete cycle of development from sterile to senile individuals on the living trees of Sorbus aucuparia. In mixed aspen-spruce forests full functional-age profiles for populations of L. pulmonaria were found on the trunks of living $P$. tremula and on dead standing trees of $S$. aucuparia and in preclimax spruce forest on dead and living $P$. tremula. In climax spruce forests, full functional-age profiles were recorded on trunks of living and dead standing P. tremula and living Picea sp. (Table 3).

In the studied forest communities, the number of thalli with apothecia varied from 0 to $12 \mathrm{pcs} / \mathrm{ha}$. The absence or minimal density of thalli with apothecia $(0-2 \mathrm{pcs} / \mathrm{ha})$ was observed in the middle-aged aspen forests and in preclimax spruce forest. The maximum values $(9$ $-12 \mathrm{pcs} / \mathrm{ha}$ ) were recorded in forests where age since disturbance corresponded to spruce-aspen 
Table 2. Substrate types, number of colonized trees and Lobaria pulmonaria thalli (in brackets) in studied forests in Vodlozersky National Park

\begin{tabular}{|c|c|c|c|c|c|c|c|}
\hline \multirow[t]{3}{*}{ Substrate types } & \multicolumn{7}{|c|}{ Number of trees, number of thalli (in brackets) } \\
\hline & \multicolumn{2}{|c|}{$\begin{array}{l}\text { Middle-aged aspen } \\
\text { forest type }\end{array}$} & \multicolumn{2}{|c|}{$\begin{array}{l}\text { Mixed aspen-spruce } \\
\text { forest type }\end{array}$} & \multirow{2}{*}{$\begin{array}{l}\text { Preclimax spruce } \\
\text { forest type } \\
5\end{array}$} & \multicolumn{2}{|c|}{$\begin{array}{l}\text { Climax (old-growth) } \\
\text { spruce forest type }\end{array}$} \\
\hline & 1 & 2 & 3 & 4 & & 6 & 7 \\
\hline Betula spp. (living) & $3(12)$ & - & - & - & $1(2)$ & $4(17)$ & - \\
\hline Betula spp. (standing dead) & - & - & - & - & - & $2(2)$ & - \\
\hline Picea spp. (living) & - & - & - & - & $3(13)$ & $15(128)$ & $11(119)$ \\
\hline Picea spp. (standing dead) & - & - & - & - & $1(5)$ & $4(28)$ & - \\
\hline Picea spp. (fallen dead) & - & - & - & $1(3)$ & - & $2(15)$ & - \\
\hline J. communis (living) & - & $1(5)$ & - & - & - & - & - \\
\hline J. communis (standing dead) & $1(2)$ & - & - & - & - & - & - \\
\hline A. incana (living) & - & - & - & - & - & - & $1(5)$ \\
\hline A. incana (fallen dead) & - & - & - & - & - & - & $1(12)$ \\
\hline P. tremula (living) & $3(10)$ & $5(16)$ & $13(60)$ & $15(65)$ & $4(30)$ & $4(34)$ & $7(70)$ \\
\hline P. tremula (standing dead) & - & - & $4(11)$ & $2(7)$ & $4(88)$ & $3(34)$ & $4(32)$ \\
\hline P. tremula (fallen dead) & - & $1(6)$ & $2(15)$ & $1(4)$ & - & $2(3)$ & - \\
\hline S. aucuparia (living) & $1(8)$ & $4(35)$ & $1(5)$ & - & $1(1)$ & $4(9)$ & $5(12)$ \\
\hline S. aucuparia (standing dead) & - & $2(9)$ & $1(11)$ & $6(33)$ & - & $2(5)$ & $3(11)$ \\
\hline S. aucuparia (fallen dead) & $1(1)$ & $4(16)$ & $1(5)$ & $1(6)$ & - & $2(4)$ & $1(1)$ \\
\hline Total (per 1 ha) & $9(33)$ & $17(87)$ & $22(107)$ & $26(118)$ & $14(139)$ & $44(309)$ & $33(262)$ \\
\hline Number of substrate types & 5 & 6 & 6 & 6 & 6 & 11 & 8 \\
\hline
\end{tabular}

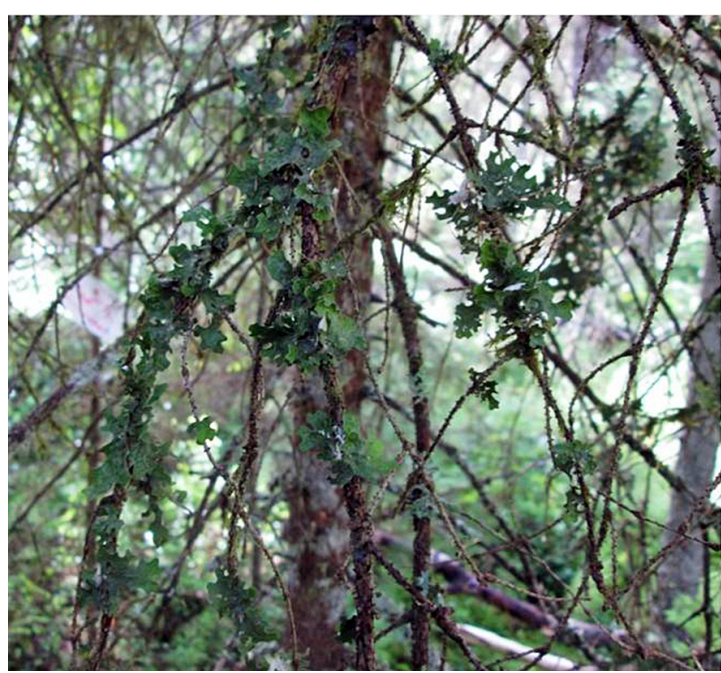

Fig. 3. Thalli of Lobaria pulmonaria on branches of young Picea spp. in the climax spruce forest Vaccinium myrtillus - green mosses type. communities and old growth forests. However, in forest communities with time-since-disturbance of 160-180 years the proportion of fertile thalli reached $9 \%$, while in old-growth spruce forests its was only $4 \%$.

\section{DISCUSSION}

The results of the present study show that time since the last forest disturbance affects significantly the quantitative and qualitative parameters of Lobaria pulmonaria populations. During the succession of forest communities, the structure of the tree stand and microclimatic conditions change (Snäll et al., 2005).

It is known that the life-cycle of Lobaria pulmonaria takes on average 35 years (Scheidegger et al., 1998; Scheidegger \& Goward, 2002). This species reproduces mainly by means of vegetative diaspores (soredia, isidioid soredia) leading to a high density of thalli within habitat of suitable conditions without disturbances (Öckinger 


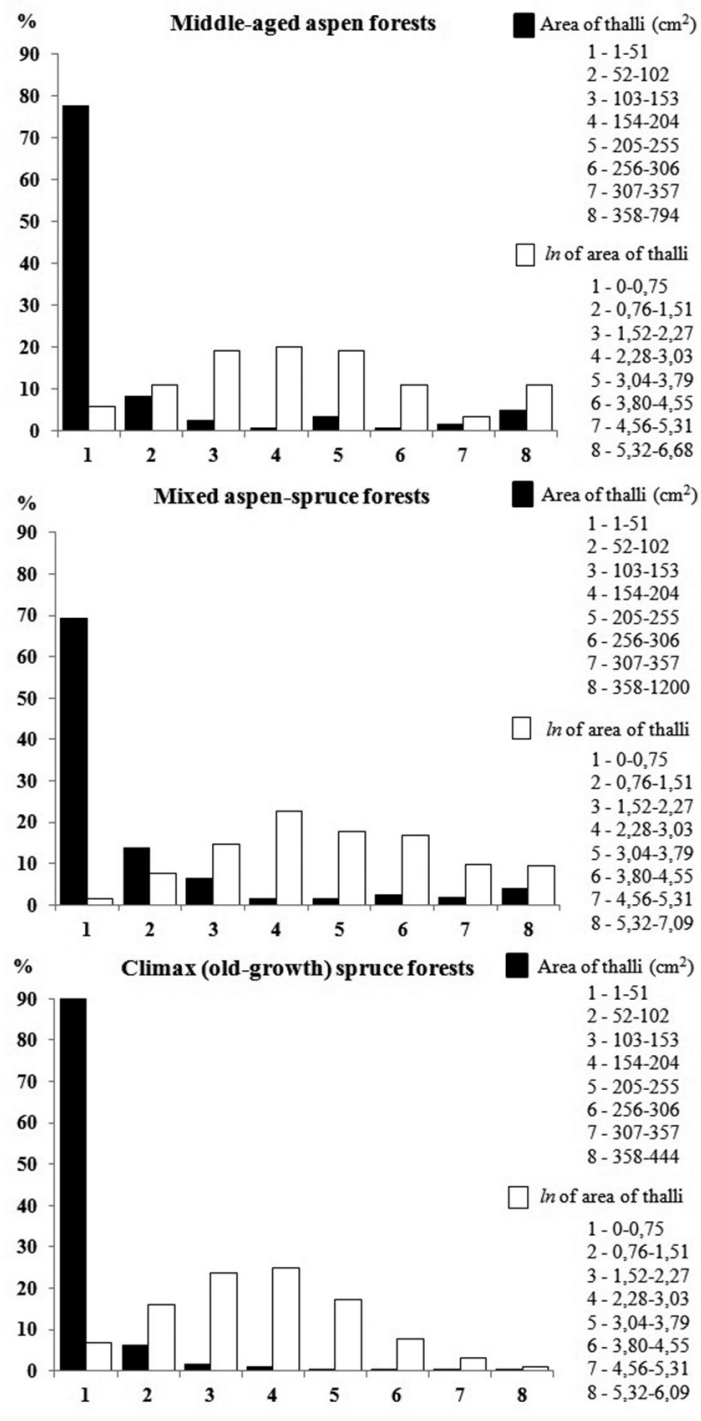

Fig. 4. Distribution of Lobaria pulmonaria thalli (\%) by area (dark shading) and by the natural logarithm of the area (no shading) in communities with different time since the last disturbance.

et al., 2005). The vegetative dispersal distance of $L$. pulmonaria is only $15-30 \mathrm{~m}$ (Jüriado et al., 2011). According to numerous reports, $L$. pulmonaria most often colonizes the trunks of large deciduous trees with a rough bark (Gu et al., 2001; Jüriado et al., 2011, 2012; Brunialti et al., 2015), which might be considered as a limiting factor in the distribution of this species.
In the conditions of Vodlozersky National Park, Lobaria pulmonaria occurs only in forest communities with an age of more than 80 years after the most recent disturbance. These communities are characterized by dense stands in which deciduous tree species predominate (72-93\%). Moreover, middle aged and mature aspen trees contribute up to $46 \%$ of these tree stands. In these communities, with an average value for basal area of $14 \mathrm{~m}^{2} \mathrm{ha}^{-1}$ and a density of crowns at $87-90 \%$, large aspens of $90-100$ years can be colonized by L. pulmonaria. It has been reported from studies in boreal-nemoral communities that the occurrence of $L$. pulmonaria is recorded in forests aged 40-60 years (Jüriado \& Liira, 2009). These authors concluded that, in addition to old-growth forests, the potential habitat of $L$. pulmonaria could be eutrophic boreo-nemoral medium-aged forest communities, with large deciduous trees. The age of these reported trees are less than is typical for phorophytes colonized by the species in less productive forests. However their size and the structure of bark surface is suitable for colonization by L. pulmonaria. In such forest communities the tree stands have high a density and their structure resembles the structure otherwise observed in old-growth forests (Jüriado \& Liira, 2009). Thus, such relatively younger forest communities might serve as corridors that connect areas of old-growth forests in a spatial network. Moreover they could play a significant role in maintaining the population of $L$. pulmonaria at a landscape level.

With the increasing time-since-disturbance, changes in the structure of the tree stand occur: the proportion of aspen in the stand decreases, and the proportion of spruce and its density increase. This leads to the transformation of habitat conditions, mainly through changes in the level and quality of light intensity and humidity (Protopopov, 1975, Gauslaa et al., 2007). In aspen forests, the light intensity and the level of insolation throughout the year vary greatly due to leaf fall in autumn. Experiments carried out in southern Norway demonstrated that the growth of Lobaria pulmonaria occurred throughout the year, but the maximum increase in biomass and area was observed from July to September (Larsson et al., 2012). It is known that intense direct sunlight can cause chlorophyll degradation in the L. pulmonaria thalli, and the consequences affect the growth of the species (Gauslaa et al., 2007). In the old-growth spruce forests, due to 
Table 3. The profile of functional-age groups for L. pulmonaria populations on its main host trees Picea spp. (Pic. spp.), Populus tremula (Pop. trem.) and Sorbus aucuparia (Sor. auc.) in the forests of Vodlozersky National Park

\begin{tabular}{|c|c|c|c|c|c|c|c|c|c|c|}
\hline \multirow[t]{2}{*}{ Type of forest } & \multirow[t]{2}{*}{ No s. p. } & \multirow[t]{2}{*}{ Substrate types } & \multicolumn{7}{|c|}{ Number of thalli in different age groups ${ }^{1}$} & \multirow{2}{*}{$\begin{array}{l}\text { Proportion of } \\
\text { thalli }(\%)\end{array}$} \\
\hline & & & st & s1 & s2 & s3 & fert & $s / \operatorname{sen}$ & sen & \\
\hline \multirow[t]{4}{*}{ Middle-aged aspen forest type } & \multirow[t]{2}{*}{1} & Pop. trem. (living) & 9 & 0 & 0 & 0 & 0 & 1 & 0 & 30 \\
\hline & & Sor. auc. (living) & 8 & 0 & 6 & 0 & 0 & 0 & 2 & 48 \\
\hline & \multirow[t]{2}{*}{2} & Pop. trem. (living) & 10 & 3 & 0 & 0 & 0 & 3 & 0 & 18 \\
\hline & & Sor. auc. (living) & 15 & 6 & 1 & 2 & 2 & 3 & 6 & 40 \\
\hline \multirow[t]{4}{*}{ Mixed aspen-spruce forest type } & \multirow[t]{2}{*}{3} & P. tremula (living) & 16 & 19 & 1 & 1 & 4 & 8 & 11 & 56 \\
\hline & & Sor. auc. (standing dead) & 1 & 6 & 0 & 0 & 2 & 1 & 1 & 10 \\
\hline & \multirow[t]{2}{*}{4} & Pop. trem. (living) & 9 & 27 & 5 & 2 & 3 & 7 & 12 & 55 \\
\hline & & Sor. auc. (standing dead) & 12 & 4 & 5 & 2 & 5 & 3 & 2 & 28 \\
\hline \multirow[t]{2}{*}{ Preclimax spruce forest type } & \multirow[t]{2}{*}{5} & Pop. trem. (living) & 13 & 6 & 5 & 1 & 0 & 2 & 4 & 22 \\
\hline & & Pop. trem. (standing dead) & 39 & 25 & 7 & 8 & 1 & 3 & 4 & 63 \\
\hline \multirow{6}{*}{$\begin{array}{l}\text { Climax (old-growth) spruce } \\
\text { forest type }\end{array}$} & \multirow[t]{3}{*}{6} & Pic. spp. (living) & 103 & 47 & 3 & 0 & 5 & 0 & 0 & 51 \\
\hline & & Pop. trem. (living) & 7 & 5 & 0 & 0 & 4 & 0 & 18 & 11 \\
\hline & & Pop. trem. (standing dead) & 3 & 12 & 3 & 1 & 2 & 2 & 11 & 11 \\
\hline & \multirow[t]{3}{*}{7} & Pic. spp. (living) & 68 & 45 & 2 & 2 & 2 & 0 & 0 & 45 \\
\hline & & Pop. trem. (living) & 3 & 24 & 2 & 7 & 3 & 4 & 27 & 27 \\
\hline & & Pop. trem.(standing dead) & 2 & 9 & 1 & 5 & 3 & 0 & 11 & 12 \\
\hline
\end{tabular}

${ }^{1}$ full names of functional age-related groups see in Material and methods

the edificatory role of spruce and the occurrence of several levels of tree canopy, a relatively stable microclimate occurs throughout the year. As a result of gap-dynamics, sunlight is diffuse, and the air is more often and more continuously saturated with water vapor, which contributes to a longer period of hydration for L. pulmonaria thalli (Merinero et al., 2014).

Meanwhile, in middle-aged aspen forests, with less stable microclimatic conditions during the year, populations of Lobaria are smaller and substrates types are less favorable. In these communities, the L. pulmonaria thalli mainly colonize the living trunks of aspen and rowan. In mixed spruce-aspen communities with an age of 160-180 years since the last disturbance, numerous large aspens (the main phorophyte of Lobaria) with roughened bark exist, which contribute to an increase in the number of thalli and their area. After the decay of a single-aged aspen tree stand (as a result of the successional change from aspen to spruce forests), in forest communities of 260-450 years, L. pulmonaria loses a significant portion of its favourable substrates. In fact, in old-growth forests aspen occurs only in the gaps of the wind-thrown complexes and its proportion in the overall tree stand decreases. In the spruce forest communities with an age of 260 years since the last disturbance the majority of thalli (63\%) were recorded on standing deadwood of aspen. Due to the favorable microclimatic conditions in these undisturbed communities L. pulmonaria begins to colonize a larger range of trees of different species and condition, including the lower branches of young spruce trees, which, even as a temporary substrate, can significantly increase the potential of the lichen for further dispersal in the forest community.

It was found during studies in the boreal forests of Canada, that young coniferous trees with the lower branches inhabited by Lobaria pulmonaria are located in the so-called "dripzone" of large old aspen (Goward \& Arsenault, 2000). The authors suggested that leaching of various compounds with precipitation from the upper part of the tree crowns of nutrient-rich aspen affected the coniferous trees with their 
crowns located below. As a result of this process the total mineral composition and $\mathrm{pH}$ of bark for coniferous trees increased. Thus, these species of tree, which are characterized by poor mineral composition and acidic bark normally, become a potential substrate for colonization by epiphytic cyanolichens, which have requirements for high $\mathrm{pH}$ values and suitable humidity conditions (Goward \& Arsenault, 2000). The researchers suggested that the "drip zone effect" is a widespread phenomenon, but it is observed only in humid communities. As a result of our studies, it was found that in spruce forests with an age of 410-450 years, the proportion of L. pulmonaria thalli on spruce was $45-51 \%$ of the total. All the coniferous trees on which the lichen was recorded were situated within a radius $1-6 \mathrm{~m}$ of a large aspen, and as consequence confirming the above hypothesis.

It has been established that with an increase of age since last disturbance from 80 to 450 years in spruce communities recovering through the aspen forest stage, the substrate preferences of Lobaria pulmonaria change. The lichen species shifts the substrate in which it completes a life cycle. In the aspen forest, full functional-age profiles might be observed only on the trunks of living Sorbus aucuparia, in mixed spruce-aspen communities on Populus tremula and standing deadwood of $S$. aucuparia, and in subclimax spruce forest on living and standing deadwood of $P$. tremula, while in climax communities on living and standing deadwood of $P$. tremula as well as on branches of Picea sp.

According to the results of our studies, the maximum proportion of fertile thalli was recorded for the spruce-aspen communities, representing $9 \%$ of the total number of thalli. In these communities there was higher number of large aspens with rough bark, which contributed positively to the increasing the number of thalli and their area. We assumed that the high density of old-growth aspen raises the probability of developing genetically diverse individuals.

In fact, there is an assumption that the formation of apothecia becomes possible only in genetically heterogeneous populations (Zoller et al., 1999). Studies of Lobaria pulmonaria in the hemiboreal forests of Estonia revealed that in managed forests the proportion of generative individuals in the population was significantly higher in comparison with old-growth communities (the age of the dominant trees was 120-190 years) and wooded meadows (Jüriado et al., 2011). However, based on molecular genetic analysis, it has been established that the high levels of genetic diversity of L. pulmonaria are within undisturbed forest communities (Jüriado et al., 2011; Scheidegger et al., 2012).

In conclusion, the Vodlozersky National Park is an important reserve for the preservation of the epiphytic cyanolichen Lobaria pulmonaria. Within its territory there are large areas of old-growth communities, and as a result of local fires, windfalls as well as overgrowing of abandoned fields, middle-aged aspen and spruce-aspen forest communities have been formed in which suitable conditions and potential substrates for colonization are created. Due to the large area of old-growth forest communities and low forest fragmentation, the $L$. pulmonaria population at a landscape (regional) level is maintained and distributed successfully through dispersal. Results of our study show that despite the long time-since-disturbance and the reduced proportion of aspen in the tree stand, there are still enough substrates for colonization of $L$. pulmonaria in old-growth forests.

\section{ACKNOWLEDGEMENTS}

We would like to express our gratitude to Roman Obabko and L'ubov Kalacheva (Petrozavodsk State University, Russia) and our relatives for help with the field work; to the administration of Vodlozersky National Park for organizing field work, to Vadim Gorshkov and Natalia Stavrova (Komarov Botanical Institute, Saint-Petersburg, Russia) for consultations on methods and on determining the time-since-disturbance in the studied forests. We are grateful to reviewers for valuable corrections and recommendations, which have improved the quality of our work. Warm thanks to Christopher Ellis (The Royal Botanic Garden Edinburgh, UK) for linguistic corrections. The study was partially supported by the Ministry of Education and Science of the Russian Federation (project No 5.8740.2017/k).

\section{REFERENCES}

Ananiev, V. A. \& Raevsky, B. V. 2010. Methodical manual on organization and conducting of forest monitoring on specially protected natural areas of Northwest Russia (on the example of National Park "Vodlozersky"). Karelian Research Center of RAS. Petrozavodsk. 42 pp. (In Russian). 
Brunialti, G., Frati, L. \& Ravera S. 2015. Structural variables drive the distribution of the sensitive lichen Lobaria pulmonaria in Mediterranean oldgrowth forests. Ecological Indicators 53: 37-42. https://doi.org/10.1016/j.ecolind.2015.01.023

Chervjakov, O. V. 2001. National Park "Vodlozersky" at the present stage of its development. National Park "Vodlozersky": the natural diversity and cultural heritage. Petrozavodsk, pp. 9-15. (In Russian).

Degteva, S. V, Zheleznova, G. V, Pystina, T. N. \& Shubina, T.P. 2001. Cenotic and floristic structure of deciduous forests of the European North. Nauka. St. Petersburg. 269 pp. (In Russian).

Dyrenkov, S. A. 1984. Structure and dynamics of boreal spruce forests. Nauka. Leningrad. 176 pp. (In Russian).

Fadeeva, M. A. \& Kravchenko, A. V. 2008. Influence of anthropogenic factors on the protected lichen Lobaria pulmonaria (L.) Hoffm. in the regional part of the area. Biodiversity: problems and perspectives of conservation: Proceedings of the International Scientific Conference devoted to the 135th anniversary of the birth of Spigina I. I. 1: 405-406. (In Russian).

Gauslaa, Y. 1995. The Lobarion, an epiphytic community of ancient forests threatened by acid rain. $L i-$ chenologist 27: 59-76. https:/ / doi.org/10.1017/ s0024282995000077

Gauslaa, Y., Palmqvist, K., Solhaug, K. A., Holien, H., Hilmo, O., Nybakken, L., Myhre, L. C. \& Ohlson, M. 2007. Growth of epiphytic old forest lichens across climatic and successional gradients. Canadian Journal of Forest Research 37(10): 1832-1845. https://doi.org/10.1139/X07-048

Goward, T. \& Arsenault, A. 2000.Cyanolichen distribution in young unmanaged forests: a dripzone effect? The Bryologist 103(1): 28-37. https:// doi.org/10.1639/0007-2745(2000)103[0028:CD IYUF]2.0.CO;2

Gromtsev, A. N. 2008. Fundamentals of landscape ecology of European taiga forests of Russia. Karelian Research Center RAS. Petrozavodsk. 238 pp. (In Russian).

Gu Wei-Dong, Kuusinen, M., Konttinen, T. \& Hanski, I. 2001. I. Spatial pattern in the occurrence of the lichen Lobaria pulmonaria in managed and virgin boreal forests. Ecography 24: 139-150. https:// doi.org/10.1034/j.1600-0587.2001.240204.x

Hanski, I. 1999. Metapopulation Ecology. Oxford University Press. 313 pp.

Ignatenko, R. V. \& Tarasova, V. N. 2015. Populations of threatened lichen Lobaria pulmonaria (L.) Hoffm. at different levels of anthropogenic load. Proceedings of Petrozavodsk State University. Biological sciences 8: 57-64. (In Russian).

Ipatov, V. S. 1960. Aspen forests types of the Northwest of the RSFSR. Bulletin of the Leningrad State University 3(1): 23-40. (In Russian).

Istomina, N. B. 1996. The biology of Lobaria pulmonaria (L.) Hoffm. and Menegazzia terebrata (Hoffm.)
Massal. in southern taiga forests of the European Russia. Cand. Sci. (Biol.) Dissertation. Moscow. 24 pp. (In Russian).

Ivanova, N. V. 2015. Factors limiting distribution of the rare lichen species Lobaria pulmonaria (in forests of the Kologriv Forest Nature Reserve). Biology Bulletin 42(2): 145-153. https: / / doi. org/10.1134/S1062359015020041

Ivanter, E. V. \& Korosov, A. V. 2011. Introduction to quantitative biology. PetrSU. Petrozavodsk. 302 pp. (In Russian).

Johansson, P. 2006. Effects of habitat conditions and disturbance on lichen diversity: studies on lichen communities in nemoral, boreal, and grassland ecosystems. Doctoral thesis. Swedish University of Agricultural Sciences Uppsala. 44 pp.

Jüriado, I. \& Liira, J. 2009. Distribution and habitat ecology of the threatened forest lichen Lobaria pulmonaria in Estonia. Folia Cryptogamica Estonica 46: 55-65.

Jüriado, I. \& Liira, J. 2010. Threatened forest lichen Lobaria pulmonaria - its past, present and future in Estonia. Forestry Studies 53: 15-24. https:// doi.org/ 10.2478/v10132-011-0086-6

Jüriado, I., Liira, J., Csencsics, D., Widmer, I., Adolf, C., Kohv, K. \& Scheidegger, C. 2011. Dispersal ecology of the endangered woodland lichen Lobaria pulmonaria in managed hemiboreal forest landscape. Biodiversity Conservation 20: 1803-1819. https: / / doi.org/ 10.1007/s 10531-011-0062-8

Jüriado, I., Karu L. \& Liira J. 2012. Habitat conditions and host tree properties affect the occurrence, abundance and fertility of the endangered lichen Lobaria pulmonaria in wooded meadows of Estonia. Lichenologist 44(2): 263-275. https:/ / doi. org/10.1017/S0024282911000727

Katenina, O. A. 1999. Epiphytic lichens as part of lichen flora of the Novgorod region. Novitates systematicae plantarum non vascularium 33: 130-138. (In Russian).

Kazimirov, N. I. 1971. Spruce forests of Karelia. Nauka. Leningrad. 139 pp. (In Russian).

Kravchenko, A. V. \& Fadeeva, M. A. 2008. Distribution and condition of Lobaria pulmonaria in the southeast of Fennoscandia. Lichens boreal forest and Fourth Russian lichenological field school. Proceedings of the international conference. Syktyvkar. Pp. 60-74. (In Russian).

Larsson, P., Solhaug, K. A. \& Gauslaa, Y. 2012. Seasonal partitioning of growth into biomass and area expansion in a cephalolichen and a cyanolichen of the old forest genus Lobaria. New Phytologist 194(4): 991-1000. https://doi.org/10.1111/ j.1469-8137.2012.04130.x

Merinero, S., Hilmo, O. \& Gauslaa, Y. 2014. Size is a main driver for hydration traits in cyanoand cephalolichens of boreal rainforest canopies. Fungal ecology 7: 59-66. https://doi.org/10.1016/j. funeco.2013.12.001

Mikhaylova, I. N. 2005. The analysis of the subpopulation structures epiphytic lichens (the case of 
Lobaria pulmonaria (L.) Hoffm.). Newsletter of Nizhny Novgorod University of N. I. Lobachev 9(1): 124-134. (In Russian).

Mikryukov, V. S., Mikhailova, I. N. \& Scheidegger, C. 2010. Reproductive Parameters of Lobaria pulmonaria (L.) Hoffm. in the Urals. Russian Journal of Ecology 41 (6): 475-479. https://doi. org/10.1134/S1067413610060032

Öckinger, E., Niklasson, M. \& Nilsson, S. G. 2005. Is local distribution of the epiphytic lichen $\mathrm{Lo}^{-}$ baria pulmonaria limited by dispersal capacity or habitat quality? Biodiversity Conservation 14: 759-773. https://doi.org/10.1007/s 10531-0044535-x

Potasheva, M. A. \& Kravchenko, A. V. 1995. Protected lichen Lobaria pulmonaria in the National Park "Vodlozersky": distribution and habitats. National Park "Vodlozersky": the natural diversity and cultural heritage. Petrozavodsk. Pp. 151-156. (In Russian).

Protopopov, V. V. 1975. Role of dark coniferous forests in the environment formation. Science. Novosibirsk. 328 pp. (In Russian).

Pystina, T. N. \& Semenova, N. A. 2009. Ecological features of lichen Lobaria pulmonaria (Lobariaceae) in the Republic of Komi. Botanical journal 94 (1): 48-58. (In Russian).

Red Data Book of Karelian Republic. 2007. Petrozavodsk. 368 pp. (In Russian).

Red Data Book of Russian Federation (plants and fungi). 2008. Moscow. 885 pp. (In Russian).

Romanov, A. A. 1961. About the Karelia climate. State Publishing House of the Karelian ASSR. Petrozavodsk. 139 pp. (In Russian).

Rose, F. 1992. Temperate forest management: it's effects on bryophyte and lichen floras and habitats. In: Bates, J. W. \& Farmer, A. (eds), Bryophytes and lichens in changing environment. Oxford, Clarendon Press. Pp. 211-233.

Scheidegger, C., Frey, B. \& Walser, J-C. 1998. Reintroduction and augmentation of populations of the endangered Lobaria pulmonaria: methods and concepts. In: Kondratyuk, S. Y. \& Coppins, B. J. (eds): Lobarion Lichens as Indicators of the Primeval Forests of the Eastern Carpathians. M. H. Kholodny Institute of Botany, Ukrainian Phytosociological Centre, Kiev. Pp. 33-52.

Scheidegger, C., Goward, T. 2002: Monitoring lichens for conservation: red lists and conservation action plans. In: Nimis, P-L., Scheidegger, C. \& Wolseley,
P-A. (eds): Monitoring with Lichens - Monitoring Lichens. Nato Science Series. IV. Earth and Environmental Sciences. Kluwer Academic Publishers. Pp. 163-181. https://doi.org/10.1007/978-94010-0423-7_12

Scheidegger, C., Bilovitz, P. O., Werth, S., Widmer, I. \& Mayrhofer, H. 2012. Hitchhiking with forests: population genetics of the epiphytic lichen Lobaria pulmonaria in primeval and managed forests in southeastern Europe. Ecology and Evolution 2(9): 2223-2240. https://doi.org/10.1002/ece3.341

Snäll, T., Pennanen J., Kivisto, L. \& Hanski, I. 2005. Modelling epiphyte metapopulation dynamics in a dynamic forest landscape. Oikos 109: 209-222. https://doi.org/10.1111/j.00301299.2005.13616.x

Stavrova, N. I., Gorshkov, V. V. \& Katyutin, P. N. 2016. Structure formation of forest tree species coenopopulations during post-fire recovery of northern taiga forests. Proceedings of the Karelian Scientific Center of RAS 3: 10-28. (In Russian).

Tarasova, V. N. \& Stepanova, V. I. 2001. Preliminary list of lichens of the National Park "Vodlozersky". National Park "Vodlozersky": the natural diversity and cultural heritage. Petrozavodsk: 183-192. (In Russian).

Tarasova, V. N., Sonina, A. V., Androsova, V. I., \& Stepanchikova, I. S. 2016. The lichens of forest rocky communities of the hill Muroigora (Arkhangelsk Region, Northwest Russia). Folia Cryptogamica Estonica 53: 111-121. https:/ / doi. org/ 10.12697 / fce.2016.53.13

Volkov, A. D. 2008. Forest types of Karelia. Karelian Research Center RAS. Petrozavodsk. 180 pp. (In Russian).

Walser, J.-C., Zoller, S., Büchler, U. \& Scheidegger, C. 2001. Species-specific detection of Lobaria pulmonaria (lichenized ascomycete) diaspores in litter sample strapped in snow cover. Molecular Ecology 10: 2129-2138. https://doi.org/10.1046/j.1365294X.2001.01353.x

Yoshimura, I. 1971. The genus Lobaria of Eastern Asia. J. Hattori Bot. Lab. 34: 231-364.

Zoller, S., Lutzoni, F. \& Scheidegger, C. 1999. Genetic variation within and among populations of the threatened lichen Lobaria pulmonaria in Switzerland and implications for its conservation. Molecular Ecology 8: 2049-2059. https://doi. org/10.1046/j.1365-294x.1999.00820.x 